Final, 24.06.14

\title{
Landesque capital as an alternative to food storage in Melanesia: irrigated taro terraces in New Georgia, Solomon Islands
}

\author{
Tim Bayliss-Smith ${ }^{1}$, Edvard Hviding ${ }^{2}$ \\ 1. Department of Geography, Downing Place, University of Cambridge, \\ Cambridge CB2 3EN, England, UK \\ 2. Department of Social Anthropology, University of Bergen, N-5020 \\ Bergen, Norway
}

\begin{abstract}
In the Pacific islands subsistence diversity made possible continuous production of food while well-developed exchange networks redistributed these foodstuffs as well as items within the prestige economy. All these were aspects of the 'storage structures' that enabled social and nutritional value to be saved, accumulated and later mobilized. In addition there were investments in the land, landesque capital, which secured future food surpluses and so provided an alternative to food storage, in a region where the staple foods were mostly perishable, yams excepted, and food preservation was difficult. Landesque capital included such long-term improvements to productivity as terraces, mounds, irrigation channels, drainage ditches, soil structural changes and tree planting. These investments provided an effective alternative to food storage and made possible surplus production for exchange purposes. As an example, in the New Georgia group of the western Solomon Islands irrigated terraces, termed ruta, were constructed for growing the root crop taro (Colocasia esculenta). Surplus taro from ruta enabled inland groups to participate in regional exchange networks and so obtain the shell valuables that were produced by coastal groups. In this paper we reconstruct how this exchange system worked in New Georgia using ethno-archaeological evidence, we chart its prehistoric rise and post-colonial fall, and we outline the factors that constrained its long-term expansion.
\end{abstract}

Key words: landesque capital, New Georgia, Solomon Islands, taro, terraces, irrigation 


\section{Ways to achieve food storage}

Food storage can be achieved through a range of practices, skills and artefacts that enable a long-term accumulation of food for future use, supported by other structures in society and in the cultural landscape that facilitate this outcome. In this paper we focus on a category of structures termed landesque capital, which result from investments in the land that help secure future food surpluses and so can provide an alternative to food storage. Landesque capital is defined by Blaikie and Brookfield $(1987,9)$ as "any investment in land with an anticipated life well beyond that of the present crop or crop cycle, ... [involving] purposive land management designed to secure future production ... [and] to create capital for future maintenance of land capability". This form of 'capital' includes such longterm improvements as terraces, mounds, dams, irrigation channels, drainage ditches, soil structural changes and tree planting (Brookfield 1984; Blaikie and Brookfield 1987; Kirch 1994; Bayliss-Smith 2007; Widgren 2011; Håkansson and Widgren 2014).

There are several possible motives for the formation of landesque capital. For people in agrarian societies reducing the risk of crop failure may have been just as important as maximising yield (Blaikie and Brookfield 1987), but often the rationale for such investments was not merely 'economic'. These transformed landscapes have symbolic and cultural meaning as well as enhanced functional value, with links to new forms of social capital, wealth inequality and gender relations (Bayliss-Smith and Hviding 2014). Although the formation of landesque capital is often a precondition for food surplus, the rationale for its formation is generally complex and should not be reduced to an 'energy storage' function.

In this paper we argue that in tropical environments where long-term storage of the staple foods was difficult or impossible, landesque capital investments provided an effective alternative strategy to ensure food security and/or to make possible a large future surplus for exchange purposes. We focus on a particular form of landesque capital, the irrigated terraced pondfields that were constructed in the islands of the tropical Pacific for growing taro (Colocasia esculenta). Most of these enhanced landscapes were abandoned with the onset of colonialism, but the evidence that survives suggests potential surplus and, by inference, associated networks of exchange. Using a case study from the western Solomon Islands, we argue that irrigated terraced pondfields (termed ruta) enabled inland populations to accumulate in the ground a surplus of taro. This surplus 
provided the means for these inland groups to participate in large-scale regional exchange systems, even though the root crop produced was a perishable food unsuited to above-ground storage.

\section{Food storage in Oceania}

A wide range of foods formed the basis for subsistence in Oceania (Melanesia, Polynesia and Micronesia), but in most island societies two root crops, taro (Colocasia esculenta) and yams (Dioscorea spp.), were the staples constituting 'the wet' and 'the dry' of Pacific agriculture (Rivers 1926; Barrau 1958; Kirch 1994; Spriggs and Matthews 2012). These two staple foods have different potentials for storage. Yam tubers are storable, but taro corms, once harvested, have a very short shelf life. In Solomon Islands taro is unfit for human consumption after 1-2 weeks, the corms quickly rotting from the attack of at least three fungal species (Gollifer and Booth 1973).

Apart from yams, in Oceania and in Island Southeast Asia before rice cultivation most other foods were perishable. In these regions people depended heavily for their subsistence on root crops, bananas, breadfruit, vegetables, pigs, fish and shellfish. Most of these foodstuffs need to be consumed within hours or days of being produced and, with few exceptions, they cannot be stored. The climate is hot and humid and lacks significant seasonal variation, so there is only limited fluctuation in the productivity of ecosystems and, except in some rainshadow areas, no prolonged drought. Therefore, for both reasons — perishability and lack of marked seasonality — storing food was not important and 'the archaeology of food storage', if strictly defined, would be a topic of limited scope. In this region other strategies, skills and social institutions served as alternatives to the usual practices of food storage.

\section{Yam storage}

Conventional above-ground storage was not altogether lacking, however, even if limited in range and long-term effectiveness. In the Solomon Islands, with some effort Canarium nuts and sago could be dried and preserved, and the salting, smoking and drying of meat, fish and shellfish might be effective in the short-term. Yams were the most storable of the important foods, and if shaded from sunlight and provided with air circulation the tubers could be kept above ground for a few months, with some wastage. Dioscorea alata and D. esculenta were the main species cultivated, requiring up to nine months from planting to maturity. On Guadalcanal at least half the crop was gradually harvested and eaten before what 
remained was dug up and stored, with storage designed as much to provide shelter for next year's planting material as to provide food for future consumption. The yam houses were located in the gardens and were temporary raised huts made of timber and leaf, about $2 \mathrm{~m}$ wide and up to $4 \mathrm{~m}$ long (Tedder and Tedder 1974, 34). After abandonment these structures quickly disappeared, leaving no archaeological trace.

Stored foods can become a form of wealth. Annette Weiner $(1983,149)$ remarks that in societies throughout the Pacific "attempts are made to produce both permanent and perishable wealth" but often it is difficult for people to use artefacts as forms of permanent wealth because the resource endowments of different islands are similar and it is not feasible to create scarcity. Weiner argues that in the Trobriand Islands one solution to this problem was to make perishable, consumable wealth (i.e. yams) take on some of the characteristics of permanence, at least for a period of time, but this had limited success because "men's wealth in yams dissipates rapidly" and a new crop must be produced year after year (Weiner 1983, 156). The polygynous Trobriand chiefs sometimes received enormous quantities of yams but they had only a brief period of time to convert the stored crop into other kinds of resources, so that in general yams created neither durable wealth nor permanent debt (Weiner 1983). Taro is even more problematic, as almost no storage is feasible for the crop except by keeping it in the ground until it is needed.

\section{Alternatives to storage}

Although yams, domestic pigs, dried sago and smoked Canarium nuts form partial exceptions, food storage was therefore difficult. Instead of storage, people's efforts were focused on cultivating social relationships so that local surpluses could meet local shortages through reciprocal exchange, and secondly on production strategies to ensure that people could enjoy a constant flow of food from garden, forest, reef and lagoon. In the Pacific food security was maintained by a high diversity of subsistence resources that were mobilised using extensive environmental knowledge (Clarke and Thaman 1993; Kennedy and Clarke 2004; Hviding 2005). This subsistence diversity was accompanied by a diversity of social options exercised through extensive kin-based exchange networks. Whether we conceptualise Oceanic societies as based on chiefs or big-men (Sahlins 1963), in each case the surplus production of perishable products took place within systems of re-distribution that made possible a substantial degree of food security and subsistence equality. Re-distribution networks were maintained by cultural 
norms that emphasised the value of social integration, exchange and the principle of delayed reciprocity.

Neither diverse sources of local subsistence nor effective local networks for food redistribution leave much trace in the archaeological record. We can infer the existence of these features of Oceanic societies by ethnographic analogy, but unless transfers of food took place between localities and in ways that incorporated stone, shell, bone or pottery, then the main foundations for food security can remain invisible. Fortunately for archaeology, however, exchange was also motivated by people's aspirations to participate in the prestige economy. Most prestige items were objects produced by carving wood, grinding stone, weaving vegetable fibres, staining artefacts with ochre or turmeric, decorating them with mother-of-pearl inlay or with feathers, or by cutting and polishing shell. The same kinship networks in which subsistence foods were transferred also formed the basis for trading networks in the prestige economy, so that indirect evidence for the 'storage' of exchange value can leave an archaeological trace. There are many examples from this region of long-distance exchange where some of the items traded (obsidian, marine shells, stone axes, pots) survive in archaeological sites, and so can provide us with proxy evidence that prehistoric societies in this region were indeed highly interconnected (Roe 2000). These exchange networks made possible everyday transfers of food as well as the exchange of prestige items, and therefore are part of the 'storage structures' that enabled social and nutritional value to be saved, accumulated and later mobilised. Landesque capital can be seen as a complementary strategy that achieved the same objective.

\section{Irrigated terraced pondfields (ruta)}

This paper will explore a form of landesque capital known as ruta in the New Georgia group of the western Solomon Islands. Here, starting from unknown origins and continuing in places into the twentieth century, taro was cultivated on terraces constructed from stone walls that formed level pondfields, irrigated by channeling water from streams (Bayliss-Smith and Hviding 2012, 2014). By controlling the flow of water through pondfields high yields of taro can be achieved, enabling a large energy surplus to be accumulated in the form of a growing crop (Spriggs 1982, 1990; Kirch 1994, 154).

Figure 1. 
Reconstructions of this system as it operated at the end of prehistory, i.e. the late nineteenth century, suggest that, once a certain point had been reached in a feasting cycle, large-scale ruta made it possible for taro to be harvested and deployed by inland people in ritual exchange with coastal groups (Tedder and Barrus 1976; Hviding 1996; Hviding and Bayliss-Smith 2000; Bayliss-Smith et al. 2003; Bayliss-Smith and Hviding 2012, 2014). Some of the taro was processed with pounded Canarium nuts and cooked to make puddings. Along with other products -- betel nut, dried Canarium nuts, feral and domestic pigs, live Phalanger cuscus, wicker shields -- the taro corms and puddings were carried down from the bush for immediate consumption. In return the coastal people provided dried fish and shellfish, coral lime, coconuts, even seawater, and various shell valuables (poata) that were produced in centres like Roviana and Marovo. Certain types of poata were valued throughout the western Solomons as markers of social status, and they could be acquired by others only in the context of exchange (Walter and Sheppard 2000, 2006; Aswani and Sheppard 2003). Therefore the people living inland could only participate in the prestige economy of poata by investing labour in the surplus production of exchangeable items, notably food, of which taro from ruta was the most important.

Dating the origins and growth of the exchange of coastal poata for inland taro remains uncertain. The earliest inland site that has been dated is a stone-faced shrine at Bao in west New Georgia, on a ridge $80 \mathrm{~m}$ above sea level. It is located $10 \mathrm{~km}$ inland from Munda and $6 \mathrm{~km}$ from the Kula Gulf and has two dates calibrated to around AD 1200 (Aswani and Sheppard 2003, S57-S59). On the basis of the more recent dates established for several coastal shrines and fortifications, archaeologists traced the expansion of the Roviana coastal chiefdoms to the late sixteenth century AD (Walter and Sheppard 2000, 314; Sheppard et al. 2000, 24). According to this scenario agricultural intensification inland would also have happened at this time.

Alternatively it is possible that ruta construction was mainly boosted by overseas contacts in the early nineteenth century. In this region interactions with Europeans began around 1800 when whalers and traders first began to visit (Bennett 1987). European sailing ships traded by bartering for water, wood and access to women, and also foods including yams, taro and coconuts. By 1840 commodities like turtle shell, beche-de-mer and copra were also being traded, and in return steel axes and later firearms were being acquired by certain coastal groups. As a result the local exchange systems rapidly intensified although later 
they were destabilised. Coastal chiefdoms such as Roviana and Marovo widened their spheres of influence and inter-island relationships of exchange and marriage were encompassed by escalating warfare and a large-scale expansion of headhunting raids. To fuel the expansion of poata exchange, slaves were acquired to produce an increased output of the shell valuables. With increasing violence the relationships between coast and bush became unbalanced, with taro from inland ruta now constructed as 'tribute' rather than exchange (McKinnon 1975; Hviding 1996; Thomas et al. 2001; Bayliss-Smith and Hviding 2012, 2014).

Before its escalation and ultimate collapse around 1900, cultivation of ruta had thus made possible an integrated system based on taro-poata exchange. Landesque capital formation enabled the exchange value of a perishable food to be accumulated in pondfields as a growing crop, kept there for weeks and months, and then used as the basis for regional transactions. As with exchange systems based on storable grain crops like rice, maize or wheat, ways were found to count the large quantities involved. In the case of Marovo, the language has a specific term for 10,000 - vuro - distinct from 1,000 (tina). According to old people the quantity vuro (as in meka vuro '[one] ten thousand', karu vuro 'twenty thousand') was reserved for counting particular items of importance, such as the huge amounts of taro amassed for the largest feasts (Bayliss-Smith and Hviding 2012, 238).

\section{Explaining taro terracing}

Some scholars once saw cultural diffusion as providing the ultimate explanation for the presence or absence of taro terracing and irrigation in Melanesia (Rivers 1926), but today these practices are usually seen as local symptoms of general processes of intensification or landesque capital formation. In this literature the explanations for irrigation in Oceania have emphasised either (1) climatic adaptation in drought-prone areas (risk reduction); or (2) population pressure (the avoidance of food scarcity); or (3) surplus production of crops for exchange (status enhancement) (Brookfield 1984, 2001; Spriggs 1982, 1990; Kirch 1994; Bayliss-Smith 2007).

In the Solomon Islands the third explanation, status enhancement, would seem to offer the best explanation for taro terracing, if we extrapolate from the ethnography. In the absence of significant seasonal risk and given the constraints on population growth imposed by hyper-endemic malaria, ruta and its equivalents are best seen as ways to achieve the storage of surplus food energy, the taro being kept in the ground to be available for future use. In this way the bush people living 
far inland, men in particular, were able to participate in a prestige economy through exchange with the coast and with other islands (Tedder and Barrus 1976; Roe 2000; Bayliss-Smith et al. 2003; Bayliss-Smith and Hviding 2012, 2014).

This explanation for the origins of taro terracing cannot easily be tested because of the limited depth and coverage of archaeological investigation in Island Melanesia. It is a region of extreme linguistic diversity encompassing both NonAustronesian and Austronesian languages, the latter connected to ultimate origins in Southeast Asia and reflected archaeologically in the onset of Lapita culture around 3,000 years ago. Taro has undoubtedly been exploited in Melanesia since the Pleistocene, but to what extent the wild taro growing in wetlands was domesticated and cultivated in pre-Lapita times remains unclear (Spriggs and Matthews 2012).

Spriggs (1999) has suggested that the initial success of Austronesian language-speakers in establishing settlements in the Bismarck and Solomon archipelagoes was because their populations expanded as a result of the "demographic advantages imparted by an integrated animal husbandry and agricultural economy in an area previously inhabited by low-density huntergatherer or low-intensity horticultural groups" (Spriggs 1999,114). The new agricultural economy was probably based on swidden cultivation as shown by evidence for erosion and proxy evidence for forest clearance (Roe 2000, 213; Grimes 2003). Terracing for taro irrigation, being a 'high-intensity' form of cultivation, should be interpreted as a symptom of the agricultural intensification of more recent times (Felgate 2007).

However, agricultural intensification appears to have taken different forms on different islands. Rivers (1926) reported that in the Solomons irrigated taro terracing was "extensive" on Kolobangara in 1908 but altogether absent from Santa Isabel and Guadalcanal. This patchy distribution in the post-contact period has been confirmed by later scholars, with no taro terracing recorded east of the Tryon-Hackman Line which divides the two main Oceanic branches of the Austronesian languages (Ross 1989). None has been found, for example, on Malaita, Makira or Santa Cruz, despite the presence on these islands of riverine sites that would appear suitable (Yen 1976, 2009). Guadalcanal provides a partial exception. Although terracing and irrigation has been absent from this island since at least the nineteenth century, it appears that north Guadalcanal was a rather different landscape in 1568 when Mendaña saw "many villages up in the hills and many plantations of food on the slopes, arranged so well that they could 
irrigate them, which they did; it was well laid out, and by each there was a stream of water" (Amherst and Thompson 1901, 306).

When Guadalcanal was next visited by Europeans nearly 400 years later, this landscape of terracing and water management had altogether disappeared. Archaeological evidence for prehistoric taro irrigation was not confirmed until David Roe $(1989,1993)$ discovered traces of stone walls, terraces and irrigated fields alongside sites for Canarium nut processing in the part of northwest Guadalcanal occupied today by Gae language speakers. He interprets this agricultural system as emerging in the context of forest degradation and the spread of grasslands, but also as an investment in landesque capital motivated by aspirations for surplus production for inter-island exchange (Roe 2000). From the abandonment of taro terracing in Guadalcanal and elsewhere, we can infer that taro terracing was sometimes a fragile landscape of intensification, easily disrupted by warfare, depopulation or shifting trade relations.

With the exception of northwest Guadalcanal all terraced taro irrigation was located west of the Tryon-Hackman line in islands where Western Oceanic languages are spoken, and especially within the Meso-Melanesian language cluster (Santa Isabel westwards to New Ireland, New Hanover and northwest New Britain). The Meso-Melanesian region also corresponds to the areas of pottery manufacture, which was largely absent east of the Tryon-Hackman line (Sheppard and Walter 2006, 54), megalithic shrines and perhaps the distinctive tomoko war canoe of the western Solomons (Felgate 2007). Irrigated taro terraces might be added to this list to generate a 'package' of linked cultural traits, but to support this neo-diffusionist model much more research is needed.

\section{Ethnoarchaeology of ruta in the New Georgia group}

There is evidence for ruta being widespread in the New Georgia group, western Solomons (Figure 2). Ruta have been reported from Kolobangara, New Georgia, Vangunu, Gatokae and Rendova (Chikamori 1966; Yen 1976, 2009; Tedder and Barrus 1976; Miller 1979; Kirch 2000:133; Hviding and Bayliss-Smith 2000). Oral histories collected by Edvard Hviding and Cato Berg suggest that Ranoga, Vella Lavella and Tetepare might also be included in the list (BaylissSmith and Hviding 2012, 2014). 


\section{Marovo Lagoon}

Hviding's ethnography from Marovo suggests that there were two basic types of ruta in New Georgia, small and large. Informants whose grandparents lived and worked in the Bareke bush, northern Vangunu, spoke of taro being planted in small beds surrounded by wooden fences or low stone walls to retain the water. These beds were divided into compartments and connected by channels. The smallest ones needed little investment beyond simple stones and logs for ponding the water and for regulating its flow from shallow pools along streams and small rivers. These small pondfields were permanently cultivated by family groups and are remembered particularly from the Piongo Lavata valley in Vahole, northern Marovo, where a few were still being maintained by elderly couples in 1996 (Hviding and Bayliss-Smith 2000, 142-3).

In addition to these small and scattered ruta and the more transitory yam swiddens, in former times the bush people maintained a number of very large communal taro plantings, both dryland and irrigated. Whereas the small familymanaged systems supplied food for everyday subsistence, the larger communal systems were designed to accumulate a food surplus for exchange purposes (Hviding and Bayliss-Smith 2000, 118).

According to old people interviewed in Vangunu in 1986, in the days "before the coming of mission and government" - up to about 1900 - "there was time for gardening only". An old man born in the bush commented that "Taro is big work to maintain; growing taro is like feeding a child. It is hard work to keep ruta, and that is why people stopped". From this we can infer that the bush people's lives revolved around the continuous needs of the irrigated taro fields. Pondfields were maintained in three stages of growth: (1) replanted tops from previously harvested taro, (2) replanted sucker corms, and (3) sprouting taro from tops or suckers. The evidence suggests that men and women co-operated in the incremental work of ruta management, with probably the men more involved in constructing walls for new terraces and irrigation channels using rocks and stones (Hviding and Bayliss-Smith 2000, 121). In Mase village, northern New Georgia, men commented in 2014 that their ancestors who built these walls must have been "giants".

\section{Mase Basin}


Margaret Tedder and Susan Barrus (1976) provide some information about how the ruta functioned as agricultural systems, based on their interviews with men from Paradise village (Menakasapa) during surveys of the upper Mase river basin. As well as taro, other important bush foods in former times included Canarium nuts, wild bananas, wild yams, cultivated bananas and sugar cane. Ceremonial feasting with taro puddings is indicated by the discovery at one inland site of an upturned, canoe-shaped food bowl (horete) in a rotten state, within a rock shelter that also contained skulls, shell valuables and some trade goods -- two clay pipes, a musket, and a broken piece of bluefigured glazed pottery (Tedder and Barrus 1976, 83). The artefacts suggest this particular site was already abandoned by 1890 , by which time muskets had been replaced by rifles and trade in firearms had been banned altogether by the Western Pacific High Commission.

Tedder's Menakasapa informants were just young boys when the last bush people moved to the coast in 1917 so their knowledge of ruta was somewhat limited:

According to informants, the terraces were planted at the beginning of the rainy season, commencing with the top terrace. It appeared that the water was shut off when planting was completed, but let in again later. The rain was carefully watched and if too much fell, water was let out. From the combined evidence of the informants and the terraces, it was deduced that water flowed through gates from one terrace to the next, though in several areas there appeared to be drains let into the system by which excess water could be removed. .... The types of taro ... used in the ruta were twice as big as these varieties are today. They said taro grown in the ruta was never diseased and never attacked by the Papuana beetle ... Our informants said that their grandfathers' whole lives revolved around the growing of taro and the maintenance that the irrigated terraces required. When the people became involved in the cash economy on the coast, they no longer found time to constantly replant within every three to five days the taro shoots after removing the tubers, which is necessary in taro cultivation. (Tedder and Barrus 1976, 46-7)

This account refers mainly to the incremental work of managing a system of ruta terraces rather than the systematic changes involved in their initial construction. It is likely that by about 1900 the inland societies were in rapid decline, their numbers reduced by warfare and disease. Their systems of exchange with coastal partners were also in crisis, as a Pax Britannica was imposed and commodity trade and Christian conversion rendered obsolete many of the old values. As a result the landesque capital inherited from the past was being managed but no longer 
created, and we therefore lack accounts of the social institutions, skills and logistics that enabled ruta to be constructed. The origins of ruta and the chronology of its expansion also remain obscure, and will remain so until its archaeology has been investigated.

\section{Field surveys of ruta}

Inland settlement in the New Georgia group was first recorded in the diary of C.M. Woodford, who was travelling through the Marovo Lagoon in October 1886. From his ship anchored at Lilihina island off the north coast of Vangunu he saw "several bush villages on the top of the range, and at one or two of them we could see houses while the existence of others is shown by wreaths of smoke" (Woodford 1886). He was told that "they are a different race and speak another language to the coast natives", and he speculated that the bush peoples were probably "earlier inhabitants of the island driven inland by the later arriving coast tribes”. Unlike Lieutenant Somerville $(1893,1897)$ a few years later, Woodford did not venture inland, so we have no eye-witness accounts of ruta management in Vangunu or elsewhere. After 1920 all inland people had re-located their settlements to coastal sites. They cultivated sweet potato and cassava as primary staples rather than taro and yams, and they produced copra rather than engaging in the ritual exchange of taro for poata shell valuables. The former settlements, sacred sites and gardens became relict features, their existence almost unknown to the outside world (Hviding and Bayliss-Smith 2000, 149-52).

\section{Kolobangara Island}

Some ruta associated with inland sites on Kolobangara were recorded in the 1970s (Miller 1979; Kirch 2000, 133-4; Yen 1976, 2009). Kirch considered that the residential sites he had found on ridges were associated with "extensive, technologically sophisticated pondfield irrigation in the valley bottoms, a kind of landesque capital intensification also found in parts of New Georgia Island" (Kirch 2000, 133-4). Kolobangara has also supplied the only radiocarbon date for ruta so far determined. Charcoal in the terrace wall of a tributary sub-system (I-6373 230 90) gave a calibrated date in the range AD 1630-1820 (Yen 2009, 173). One date is not a secure basis for generalisation but it is at least consistent with chronologies established for Roviana Lagoon on New Georgia. Aswani and Sheppard (2003) suggest that it was only after AD 1600 that the Nusa Roviana chiefdom had an increased capacity to mobilise resources from the wider region, including perhaps food supplies from inland sites of ruta intensification (see also Walter and 
Sheppard 2000, 2006). Given the pre-eminence at feasts of puddings made from grated and pounded taro and Canarium nuts, it is reasonable to suggest that taro supplied from inland areas and from neighbouring islands like Kolobangara was part of the prestige economy of the expanding lagoon chiefdoms of New Georgia

\section{Gatokae Island}

A small-scale abandoned ruta in Vao, Gatokae island was mapped by Graham Baines in 1982 (Figure 3). There are three separate gardens containing eleven, six and nine pondfields respectively, with the dry stone walls that support each terrace varying in height from 0.10 to $0.45 \mathrm{~m}$ (mean $0.25 \mathrm{~m}$ ). The gardens are surrounded by channels fed by a natural stream, the inflow of water being controlled by stone weirs. The 26 pondfields at Vao are mostly small, each one averaging only $26 \mathrm{sq} \mathrm{m}$. The cultivable area (total $673 \mathrm{sq} \mathrm{m}$ ) represents about 48 per cent of the total cleared area including channels, banks and walls. The work of planting, weeding and harvesting the three sets of pondfields was probably individual, but perhaps their owners cooperated in the work of bush clearance, digging ditches, building weirs and managing the flow of water.

Figure 3

\section{North New Georgia}

Larger scale systems are best documented in the Kusaghe districts of northern New Georgia, where an estimated 100 hectares of ruta were cultivated in the upper Mase river basin (Tedder and Barrus 1976, 41). This whole area had been subject to severe depopulation in the decades before and after 1900. Pioneer missionary Rev. J. F. Goldie thought that in former times each inland village might have had 40-50 inhabitants, but the last survivors moved to the coast in 1917. Fifty-five years later Tedder and Barrus (1976) mapped the total extent of ruta in the upper Mase basin, made surveys of sacred sites and located the sites of 15 abandoned villages. This figure suggests (using Goldie's estimate) a total inland population of 600-750 people. They calculated that if just one-third of the $24 \mathrm{sq}$ $\mathrm{km}$ of arable land in the Mase basin were cultivated for swiddens, then the area could have supported at least 1,000 people (Tedder and Barrus 1976, 48). If we also take into account the total area of ruta, then even larger populations can be 
calculated (Bayliss-Smith et al. 2003), but in generating such estimates we have to assume that the settlement sites and ruta systems were all in simultaneous use.

No sub-surface archaeology has been attempted in the upper Mase, so we can only attempt a partial reconstruction of this inland society. According to Tedder and Barrus (1976) settlement sites were connected by graded paths 2-5 m wide, as also observed on Vangunu by Somerville $(1893,1897)$. The sites contained house platforms, standing stones, rock art and sacred sites with skull shrines, shell valuables and, on occasion, nineteenth century trade goods. The villages were mostly situated at altitudes just below $400 \mathrm{~m}$ but in two cases were as high as $600 \mathrm{~m}$ above sea level (Tedder with Barrus 1976:42).

Tedder and Barrus $(1976,42)$ also made sketch maps of two terrace systems at Kapoara and Lilosana on the south side of the Mase river, both of which are larger than the ruta at Vao. At Lilosana some terrace walls had been damaged by floods but there were traces of 14 pondfields covering at least 1,600 sq $\mathrm{m}$. At Kapoara there were also 14 pondfields covering 1,900 sq. m. As at Vao there was no oral history to indicate the reason for intensified taro production at these sites, whether for local subsistence or for external exchange, but given the sheer scale of ruta construction in this area some external stimulus seems likely. In 2014 the chief of the Lupa landowning group that is now based in the coastal villages of Mase and Jela still retained a list of the names of Lupa sites north of the Mase river, including 19 ruta, nine villages and six sacred sites, all long abandoned and now covered in dense secondary rainforest.

During Bayliss-Smith's reconnaissance surveys of the Mase basin in January 2014 some even larger ruta systems were surveyed and mapped. One was constructed on an old river terrace of the Malangari river, a tributary of the Mase, and is well preserved under forest apart from some erosion of the uppermost terrace by the encroaching river (Figure 4). The flight of terraces rises in 14 steps defined by stone walls that average $0.4 \mathrm{~m}$ in height, defining terraces with a total area potentially cultivable of 7,125 sq. m (internal pondfield area excluding walls). If we adopt Kirch's $(1994,175)$ conservative yield estimate from Futuna pondfields of $25 \mathrm{t} / \mathrm{ha} / \mathrm{yr}$ of taro corms, the Malangari ruta could have produced an annual yield of about 18 tonnes of taro to feed the local population and/or to use for exchange with coastal partners.

Figure 4 


\section{Landesque capital as food storage: limits to growth}

This paper has argued that the evidence from the western Solomons suggests that using irrigated terraces (ruta) for taro production enabled inland groups to acquire shell valuables (poata) through exchange transactions with coastal partners. Three possible constraints on the expansion of this system of intensified production and food storage can be suggested.

\section{Ecological constraints}

In some sites a shortage of suitable land reduced the potential for terrace formation. The steeper the topography, the greater the work needed to terrace the landscape and channel water to irrigate pondfields. Flat areas close to rivers are often too stony and may be liable to flood, whereas naturally formed river terraces are ideal sites for improvement by constructing modest stone walls. For example, the Vao ruta (see Figure 3) has stone-faced terraces that rise in 17 steps with an average height difference of only $0.25 \mathrm{~m}$ between adjacent terraces. More steeply sloping valleys could still be terraced, but at the cost of narrower pondfields and higher walls, some of them up to $2.5 \mathrm{~m}$ high in the Hiniburu (Tonggere) valley in the Mase basin. On Simbo in the New Georgia group terracing was altogether lacking, a reflection of the island's topography of short steep valleys, no major watercourses and permeable soils. Here ruta were never formed and instead the Simbo people focused their efforts on bananas, yams and tree crops, importing taro (probably ruta-grown) from neighbouring islands (Hocart 1908).

\section{Unstable exchange relations}

The inherent instability of the exchange relationships that underlay agricultural intensification in this region may also have constrained growth. In the New Georgia group exchange took place between diverse societies speaking at least fifteen languages, some of them non-Austronesian (Wurm and Hattori 1983). The incentives may not have been sufficient for inland societies to construct or maintain ruta in order to accumulate surplus value. Perhaps the demand from inland for shell valuables or dried fish was not consistently strong, or perhaps the coastal people themselves sometimes broke off relations and sought alternative exchange partners living elsewhere. Coastal groups were no doubt tempted (as in the nineteenth century) to appropriate using violence what they could otherwise only obtain by peaceful barter, with negative effects on the sustainability of the whole exchange system. 


\section{Hyper-endemic malaria}

Lowland New Guinea, Solomon Islands and Vanuatu are among the most hyper-endemic malarious regions of the world (Carter and Mendis 2002). Before the 1960s there were high mortality rates in Solomon Islands, with $40-60 \%$ of children dying from some form of malaria infection before they reached the age of 5 years. There were also very high rates of maternal anaemia, miscarriages and stillbirths, and birth weights for babies were low in a high proportion of cases (Black 1955; MacGregor 1968; MacGregor and Avery 1974; Müller et al. 2003). Only inland populations in islands like Kolobangara and New Georgia, cultivating ruta in the valleys but mostly living in scattered hamlets on ridge tops above 300 $\mathrm{m}$, achieved some protection. In such populations most infections occur in adolescents and adults, as happens today in areas bordering the fringe Highlands in Madang province, Papua New Guinea (Mueller et al. 2007).

With infrequent infection there is only limited acquisition of effective immunity to malaria, and most infections are acquired through contact with people who live in holoendemic coastal areas. Bush populations are therefore in the phase known as 'unstable endemic malaria' because their protective immunity is unreliable in older age groups (Carter and Mendis 2002, 567). This unstable situation is in contrast to 'stable endemic malaria' which occurs with the high population densities and perennial transmission that allows for frequent malaria inoculation. In the latter phase high infant mortality is balanced by high fertility, and the survivors of childhood infection have partial immunity to local malaria strains (Carter and Mendis 2002, 568).

Populations in the inland areas of New Georgia would have been in the unstable endemic phase, while coastal chiefdoms must have achieved the stable endemic phase with large settlements containing hundreds of people reaching the densities needed for repeated infection. Their acquired immunity to malaria infection was rather localized so that mobility was penalised, and population growth may have been difficult for these coastal centres without an influx of women and slave labourers acquired through raiding (Bayliss-Smith and Hviding 2012). This demographic instability made the expansion of alternatives to food storage such as ruta difficult to sustain, and it also encouraged the linguistic diversity that is so characteristic of Island Melanesia.

\section{Conclusion}

The humid tropics imposed some distinctive ecological constraints on food storage, especially where subsistence was based on non-grain staples as in 
Oceania. In Solomon Islands, for example, taro, bananas and breadfruit all have limited potential for storage as does pork and most seafoods, and only yams can be stored post-harvest for some months. To a large extent the problems posed by the perishability of food were solved through social strategies involving reciprocal exchange which served to redistribute short-term surpluses, and by environmental strategies that maximised the diversity of foods consumed. Problems of food storage emerged primarily in the context of the prestige economy, where the enhancement of social status required perceived value to be accumulated prior to occasions of feasting or ceremonial gift exchange.

While food storage in the strict sense was difficult and often limited in scale, an accumulation of growing crops in the ground was possible through agricultural strategies some of which involved landesque capital formation. However, we should not assume that the rationale for such investments, for example mounding, ditching, terracing or irrigation, was solely to achieve an alternative to food storage. Other factors might include group survival in the face of population pressure, reducing the risk of harvest failure to counter seasonal or other fluctuations, or helping ambitious leaders to build social capital through enduring landscape transformation.

In Melanesia, however, status enhancement was probably the main motive for the intensification of agriculture, with or without landesque capital formation. The explanation is supported by the case study from western Solomons of irrigated terracing for taro (ruta) that is presented in this paper. Surplus production was achieved in the western Solomons mainly through pondfield construction in valley sites that were cleared from rainforest, terraced and irrigated. These practices made possible food accumulation in growing crops. The evidence from New Georgia suggests that regional exchange systems were centred on chiefdoms like Nusa Roviana that only expanded after AD 1300 and especially after AD 1600 (Walter and Sheppard 2000, 2006; Aswani and Sheppard 2003).This process reached its peak in the nineteenth century when large-scale coastal feasting and raiding required an even high intensification of ruta, from which crops were channeled to coastal chiefdoms partly through coercion.

It therefore seems likely that the exchange of taro and other bush foods for shell valuables was the main stimulus for an expansion of irrigated terracing (ruta) in inland areas, which provided a successful alternative to above-ground food storage. However, in the western Solomons generally there were constraints on agricultural intensification, political expansion, population growth and the nucleation of settlement, with hyper-endemic malaria as the most intractable of 
these limiting factors. The comparison with adjacent regions of the Pacific that were non-malarial (New Caledonia, Fiji, Polynesia) shows that a more substantial investment in landesque capital would have been feasible in New Georgia, with concomitant changes in capacity for food surplus, social stratification and population expansion. Throughout the malarial zone of Island Melanesia such changes happened only to a limited extent, because of interacting environmental, epidemiological and social factors that placed limits on the long-term process of political centralisation.

\section{Acknowledgements}

Our gratitude for support during earlier fieldwork in the New Georgia group has already been expressed in previous publications. The Kusaghe fieldwork of TBS in 2014 would not have been possible without help from Inga-Maria Mulk, Tony Heorake, Aseri Yalongono, Kenneth George Ginabule, Turi Jacob, Nixon and Anita Tigina, and the ruta survey team from Mase (Rendol Reke, Leeman Piano, Antony Tupiti and Presah Koba). We are also grateful to Kylie Moloney and Bernadette Hince for their assistance with archival work in Canberra, and Philip Stickler (Cambridge) for his help with cartography. We particularly thank Susan Rogers (formerly Barrus) whose 1974 field notes, recently donated to the Cambridge Museum of Archaeology and Anthropology, allow us to re-draw more accurately the ruta maps. The 2014 project was supported by the Smuts Fund and Foreign Travel Fund, University of Cambridge, and by St John's College, Cambridge. 


\section{List of Figure captions}

Figure 1. Island Melanesia, showing islands and localities mentioned in the text and the Tryon-Hackman line that separates the two main Oceanic branches of the Austronesian language family.

Figure 2. The New Georgia group, western Solomon Islands, showing the islands and localities where ruta terracing has been reported or surveyed (see text for further details).

Figure 3. (a) Map of a small-scale ruta in Vao, Gatokae Island, showing the terrace walls and land- and water-surface elevations (source: G.B.K. Baines, field survey 1982, unpublished); (b) Cross-section through the Vao ruta, with the vertical scale exaggerated five times (after Hviding and Bayliss-Smith 2000, 135).

Figure 4. Map of a large-scale ruta situated on the Malangari river, Mase basin, northern New Georgia (source: Bayliss-Smith, field survey January 2014) 


\section{$\underline{\text { References }}$}

Amherst, Lord, of Hackney and Thomson, B. (eds.) 1901. The Discovery of the Solomon Islands by Alvaro de Mendaña in 1568: Translated from the Original Spanish Documents, vol. 2. London: Hakluyt Society.

Aswani, S. and Sheppard, P. 2003. The archaeology and ethnohistory of exchange in precolonial and colonial Roviana. Current Anthropology 44 supplement, S51S78.

Barrau, J. 1958. Subsistence Agriculture in Melanesia. Honolulu: Bernice P. Bishop Museum, Bulletin 219.

Bayliss-Smith, T. 2007. The meaning of ditches: Interpreting the archaeological record from New Guinea using insights from ethnography, pp. 126-48 in Denham, T.P., Iriarte, J., and Vrydaghs, L. (eds.), Rethinking Agriculture: Archaeological and Ethnoarchaeological Perspectives. Walnut Creek, California: Left Coast Press.

Bayliss-Smith, T. and Hviding, E. 2012. Irrigated taro, malaria and the expansion of chiefdoms: ruta in New Georgia, Solomon Islands, pp. 219-54 in Spriggs, M., Addison, D. and P.J. Matthews, P.J. (eds.), Irrigated Taro (Colocasia esculenta) in the Indo-Pacific. Biological, Social and Historical Perspectives. Osaka: Senri Ethnological Studies 78, National Museum of Ethnology.

Bayliss-Smith, T. and Hviding, E. 2014. Taro terraces, chiefdoms and malaria: explaining landesque capital formation in Solomon Islands, pp. 75-97 in Håkansson, N.T. and Widgren, M. (eds.), Landesque Capital: The Historical Ecology of Enduring Landscape Modifications. Walnut Creek, California: Left Coast Press.

Bayliss-Smith, T., Hviding, E. and Whitmore, T. 2003. Rainforest composition and histories of human disturbance in the Solomon Islands. Ambio 32, 346-52. 
Bennett, J.A. 1987. Wealth of the Solomons. A History of a Pacific Archipelago, 1800-1978. Honolulu: University of Hawai'i Press.

Black, R.H. 1955. Malaria in the Southwest Pacific. Noumea: Technical Paper 81, South Pacific Commission.

Blaikie, P. and Brookfield, H.C. 1987. Land Degradation and Society. London: Taylor \& Francis.

Brookfield, H.C. 1984. Intensification revisited. Pacific Viewpoint 25, 15-44.

Brookfield, H.C. 2001. Intensification and alternative approaches to agricultural change. Asian Pacific Viewpoint 42, 181-192.

Carter, R. and Mendis, K.N. 2002. Evolutionary and historical aspects of the burden of malaria. Clinical Microbiology Reviews 15 (4), 564-94.

Chikamori, M. 1966. Preliminary Report on Archaeological and Ethnological Research in the Western Solomon Islands (in Japanese, English summary). Tokyo: Kaimedo [cited by Spriggs 1990].

Clarke, W.C. and Thaman, R.R. 1993. Agroforestry in the Pacific Islands: Systems for Sustainability. Tokyo, London, Paris: United Nations University Press.

Felgate, M. 2007. Leap-frogging or limping? Recent evidence from the Lapita littoral fringe, New Georgia, Solomon Islands, pp. 123-40 in Bedford, S., Sand, C. and Connaughton, S.P. (eds.), Oceanic Explorations: Lapita and Western Pacific Settlement. Canberra: Terra Australia 26, ANU E Press.

Gollifer, D.E. and Booth, R.H. 1973. Storage losses of taro corms in the British Solomon Islands Protectorate. Annals of Applied Biology 73, 349-56.

Håkansson, N.T. and Widgren, M. (eds.) 2014. Landesque Capital: The Historical Ecology of Enduring Landscape Modifications. Walnut Creek, California: Left Coast Press. 
Hocart, A.M. 1908. Gardens and Food Plants. Mangedusu (Simbo), 1908

Fieldwork, Hocart and W.H.R., Rivers. Wellington: Turnbull Library, unpublished manuscript.

Hviding, E. 1996. Guardians of Marovo Lagoon: Practice, Place and Politics in Maritime Melanesia. Honolulu: University of Hawai'i Press.

Hviding, E. 2005. Reef and Rainforest: An Environmental Encyclopedia of Marovo Lagoon, Solomon Islands / Kiladi oro vivineidi ria tingitonga pa idere oro pa goana pa Marovo. Paris: UNESCO, Knowledges of Nature Series, No. 1. Paris: UNESCO (revised edition 2011).

Hviding, E. and Bayliss-Smith, T. 2000. Islands of Rainforest. Agroforestry, Logging and Ecotourism in the Solomon Islands. Aldershot: Ashgate.

Kennedy, J. and Clarke, W.C. 2004. Cultivated Landscapes of the Southwest Pacific. Canberra: Research School of Pacific and Asian Studies, Australian National University, Resource Management in Asia-Pacific Working Paper 50.

Kirch, P.V. 1994. The Wet and the Dry: Irrigation and Agricultural Intensification in Polynesia. Chicago: University of Chicago Press.

Kirch, P.V. 2000. On the Road of the Winds: An Archaeological History of the Pacific Islands before European Contact. Berkeley and Los Angeles: University of California Press.

McGregor, J.D. 1968. Malaria in the Island Territories of the Pacific. Honiara, Solomon Islands: Government Printing Office.

McGregor, J.D. and Avery, J.G. 1974. Malaria transmission and fetal growth. British Medical Journal 3 (17 August), 433-436.

McKinnon, J. 1975. Tomahawks, turtles and traders: a reconstruction of the circular causation of warfare in the New Georgia group. Oceania 45, 290-307.

Miller, D. 1979. Solomon Islands National Sites Survey Summary Report. Honiara: National Museum. 
Mueller, I., Yala, S., Ousari, M., Kundi, J., Ivivi, R., Saleu, G., Sie, A. and Reeder, J. 2007. The epidemiology of malaria in the Papua New Guinea Highlands. 6. Simbai and Bundi, Madang Province. Papua New Guinea Medical Journal 50 (34), 123-133.

Müller, I., Bockarie, M., Alpers, M. and Smith, T. 2003. The epidemiology of malaria in Papua New Guinea. Trends in Parasitology 19, 253-259.

Rivers, W.H.R. 1926. Irrigation and the cultivation of taro, pp. 262-87 in Elliot Smith, G. (ed.), W.H.R. Rivers, Psychology and Ethnology. London: Kegan Paul, Trench, Trubner \& Co.

Roe, D. 1989. The Kolevu Valley terraced taro system, west Guadalcanal, pp. 20511 in IBSRAM, Soil Management and Smallholder Development in the Pacific Islands. Bangkok: International Board for Soil Research and Management, Proceedings 8.

Roe, D. 1993. Prehistory without Pots: Prehistoric settlement and economy of Northwest Guadalcanal, Solomon Islands. Unpublished Ph.D thesis, Australian National University, Canberra.

Roe, D. 2000. Maritime, coastal and inland societies in Island Melanesia: the bushsaltwater divide, pp. 197-222 in O'Connor, S. and Veth, P. (eds.), East of Wallace's Line. Studies of Past and Present Maritime Cultures in the Indo-Pacific Region. Rotterdam and Brookfield, Vermont: Balkema.

Ross, M. 1989. Early Oceanic linguistic prehistory: a reassessment. Journal of Pacific History 24, 135-49.

Sahlins, M.D. 1963. Poor man, rich man, big man, chief: political types in Melanesia and Polynesia. Comparative Studies in Society and History 5, 285-303.

Sheppard, P. and Walter, R. 2006. A revised model of Solomon Islands culture history. Journal of the Polynesian Society 11, 47-76. 
Sheppard, P., Walter, R. and Nagaoka, T. 2000. The archaeology of head-hunting in Roviana Lagoon. Journal of the Polynesian Society 109, 9-37.

Somerville, B.T. 1893. 'Report concerning the Bush in the Vicinity of Lihihina Island, Marovo Lagoon, New Georgia, Solomon Islands'. Unpublished report addressed to Commander A.J. Balfour, H.M.S. Penguin. London: Balfour Collection, Royal Geographical Society.

Somerville, B.T. 1897. Ethnographical notes in New Georgia, Solomon Islands. Journal of the Royal Anthropological Institute of Great Britain and Ireland 26, $357-413$.

Spriggs, M. 1982. Taro (Colocasia esculenta) irrigation techniques in the Pacific: labour inputs, yields and cropping cycles, pp. 256-71 in IFS Regional Meeting on Edible Aroids, Suva, Fiji, November 1981. Stockholm: IFS Provisional Report 11.

Spriggs, M. 1990. Why irrigation matters in Pacific prehistory, pp. 174-89 in Yen, D.E. and Mummery, J.M.J. (eds.), Pacific Production Systems: Approaches to Economic Prehistory. Canberra: Department of Prehistory, Research School of Pacific Studies, Occasional Papers in Prehistory 18.

Spriggs, M. 1999. Pacific archaeologies: contested ground in the construction of Pacific history. Journal of Pacific History 34, 109-21.

Spriggs, M. and Matthews, P.J. 2012. Irrigated taro in the indo-Pacific: multiple perspectives, pp. 341-7 in Spriggs, M., Addison, D. and P.J. Matthews, P.J. (eds.), Irrigated Taro (Colocasia esculenta) in the Indo-Pacific. Biological, Social and Historical Perspectives. Osaka: Senri Ethnological Studies 78, National Museum of Ethnology.

Tedder, M.M. and Barrus, S. 1976. Old Kusaghe. Journal of the Cultural Association of the Solomon Islands 4, 41-95.

Tedder, M.M.. and Tedder, J.L.O. 1974. Yams. A Description of their Cultivation on Guadalcanal in the Solomon Islands. Noumea: South Pacific Commission, Technical Report 169. 
Thomas, T., Sheppard, P. and Walter, R. 2001. Landscape, violence and social bodies: ritualized architecture in a Solomon Islands society. Journal of the Royal Anthropological Institute N.S., 7, 545-72.

Walter, R. and Sheppard, P. 2000. Nusa Roviana: the archaeology of a Melanesian chiefdom. Journal of Field Archaeology 27, 295-318.

Walter, R. and Sheppard, P. 2006. Archaeology in Melanesia: a case study from the Western province of the Solomon Islands, pp. 137-59 in Lilley, I. (ed.), Archaeology of Oceania: Australia and the Pacific Islands. Malden, USA, Oxford, UK and Carlton, Australia: Blackwell.

Weiner, A.B. 1983. 'A world of made is not a world of born': doing kula on Kiriwina, pp. 147-70 in Leach, J.W. and Leach, E. (eds.), The Kula. New Perspectives on Massim Exchange. Cambridge: Cambridge University Press.

Widgren, M. 2011. Pre-colonial landesque capital: a global perspective, pp. 61-77 in Hornborg, A., Martinez-Alier, J., and Mcneill, J.R. (eds.), Rethinking Environmental History: World-System History and Global Environmental Change. Walnut Creek, California: AltaMira Press.

Woodford, C.M. 1886. 'Diary from $4^{\text {th }}$ August 1886 to November $10^{\text {th }} 1886$. Chas. M. Woodford, F.R.G.S., Gravesend, England' (unpublished). Canberra: Pacific Manuscripts Bureau, Australian National University, PMB 1290.

Wurm, S. and Hattori, S. 1983. Language Atlas of the Pacific Area. Canberra: Australian Academy of the Humanities.

Yen, D.E. 1976. Agricultural systems and prehistory in the Solomon Islands, pp. 61-74 in Green, R.C. and Cresswell, M.M. (eds.), South East Solomons Cultural History. Wellington: Royal Society of New Zealand, Bulletin 11.

Yen, D.E. 2009. Ethnobotany in the Southeast Solomon Islands Cultural History Project, pp. 173-9 in Sheppard, P.J., Thomas, T. and Summerhayes, G. (eds.) Lapita: Ancestors and Descendants. Auckland: New Zealand Archaeological Association Monograph. 